\title{
A Simple Safety-Loop for Restraining the Cynomolgus Monkey
}

\author{
Michihiro T. SUZUKI, Fumio OHKUBO, \\ *Fumiaki $\mathrm{CHO}$ and *Shigeo HONJO \\ The Corporation for Production of Laboratory Primates, and *Tsukuba Primate \\ Center for Medical Science, The National Institute of Health. \\ Hachimandai, Yatabe-machi, Tsukuba-gun, \\ Ibaragi-ken 305, Japan.
}

(Received for publication, : October 19, 1979)

\begin{abstract}
A simple safety-loop for restraining the cynomolgus monkey was devised. The loop is used lest an animal technician should be bitten by a monkey when the monkey is handled for injection, blood-taking, temperature-taking and rectal swabbing etc. under not-anesthesized conditions. The shape and size of the loop are shown by Figures 1 and 2. Figures 3 to 8 illustrate how to use the loop. Experiences of frequent use revealed the following points. (1) It is very easy to put the loop on and off. (2) An animal technician can safely deal with a monkey being put the loop on, as the monkey can not shut the mouth. (3) The loop can easily be washed, disinfected and sterilized. It does not need wide area to hold the loop when it is not used. (4) It is very simple and cheap to make up the loop. (5) The loop is fairly durable, that is, the teflon-tube of the loop was slightly broken at last after more than one hundred uses. (6) There appeared a few monkeys suffering from a minor injury on their mouth corners.
\end{abstract}

\author{
カニクイザルの簡単な保定補助具について \\ 鈴木通弘・大久保文雄 $\cdot *$ 長 文昭 $\cdot *$ 本庄重男 \\ 社団法人予防衛生協会 \\ *国立予研筑波医学実験用霊長類センター
}

近年, 実験動物としてのサル類の使用は増加の一途を たどっている。ところで, 現在使用されているサル類

（以下 サルと略記）についてみると, ほとんどが野生 由来であるので, ヒトに対して危険な病気を持っていた り，咬みついたりする恐れが大きい。したがって，その 安全な取扱い方法は大きな問題である $[3,5]$ 。

サルを安全に取扱らにはできるだけ麻酔処置をするの が良いとされているが, 状況や目的によっては無麻酔で 行わねばなら婸合もある $[5]$ 。さて，無麻酔下でのサ ル保定法についてみると種々の方法 $[1,2,3,4,5]$ が考案
・実施されている。そのひとつである腕部把持法（保定 者はサルの両腕を背側に回して片手で把握し, 他方の手 で両脚もしくは後頸部を把握する方法）は種々の処置の 際おこなわれているが, 保定者および術者がサルに咬ま れる可能性があるので, それを防ぐ為サルのロの位置を 常に注意して処置しなければならないといら久点がある。 そこで著者らはこの腕部把持法を用いて作業する際, サ ルに咬まれることなく安全に取扱らことができるよらに するための極めて簡単な補助具を考案したので報告す る。 


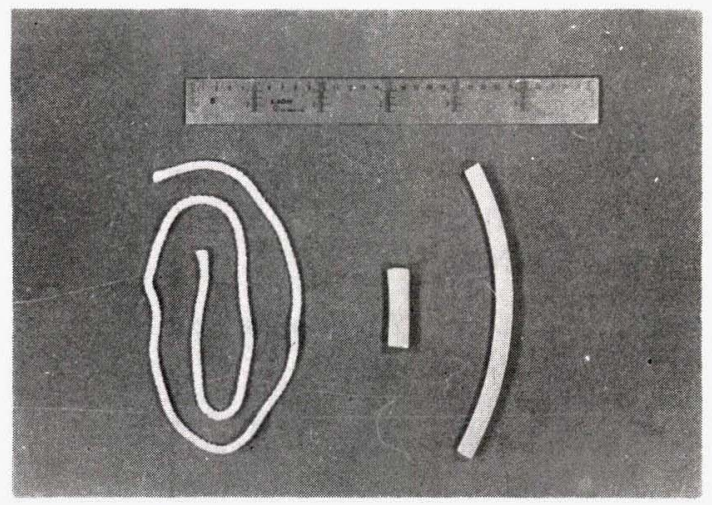

Fig. 1 Parts of the safety-loop, (1) A $90 \mathrm{~cm}$ long cottoncord (2) A $\phi 1.2 \mathrm{~cm} \times 20 \mathrm{~cm}$ long teflon tube (3) A $\phi 1.5 \mathrm{~cm} \times 5 \mathrm{~cm}$ long teflon tube.

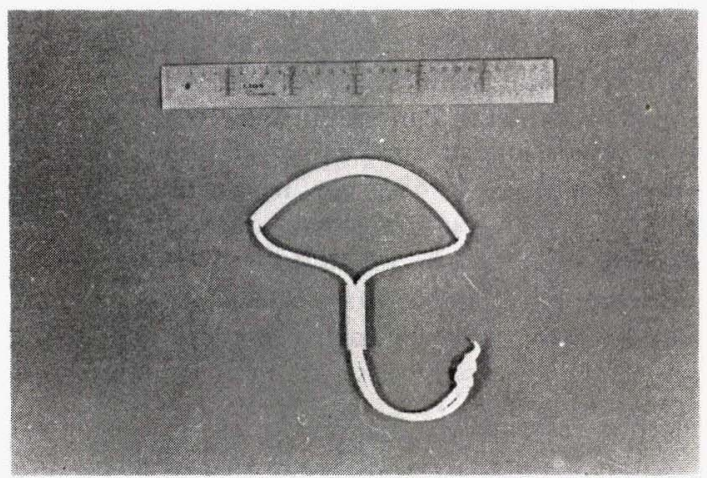

Fig. 2 The safety-loop made up.

\section{材料}

Fig. 1 に本具を作製する材料を示した。すなわち, 直径 $4 \mathrm{~mm} \times$ 長さ約 $90 \mathrm{~cm}$ の木綿製紐 (以下紐と略記) 1 本, 直径 $1.2 \mathrm{~cm} \times$ 長さ約 $20 \mathrm{~cm}$ で内径 $6 \mathrm{~mm}$ のテフロン チューブ (20cmチューブと略記) 1 本, 直径 $1.5 \mathrm{~cm} \times$ 長 さ約 $5 \mathrm{~cm}$ で内径 $1 \mathrm{~cm}$ のテフロンチューブ $5 \mathrm{~cm}$ チュー ブと略記） 1 本である。

\section{作製方法}

紐の片端より $20 \mathrm{~cm}$ チューブを通し, 次に紐の両端を 合せ $5 \mathrm{~cm}$ チューブを通し，最後に紐の両端を結んで作 製する (Fig. 2)。

\section{使用方法}

装着方法 : 保定者はあらかじめサルの両腕を背側に回 して片手で把握している（Fig. 3)。他方の手で本具の 20cmチューブ部分をサルのロに近つける (Fig. 4)。サ

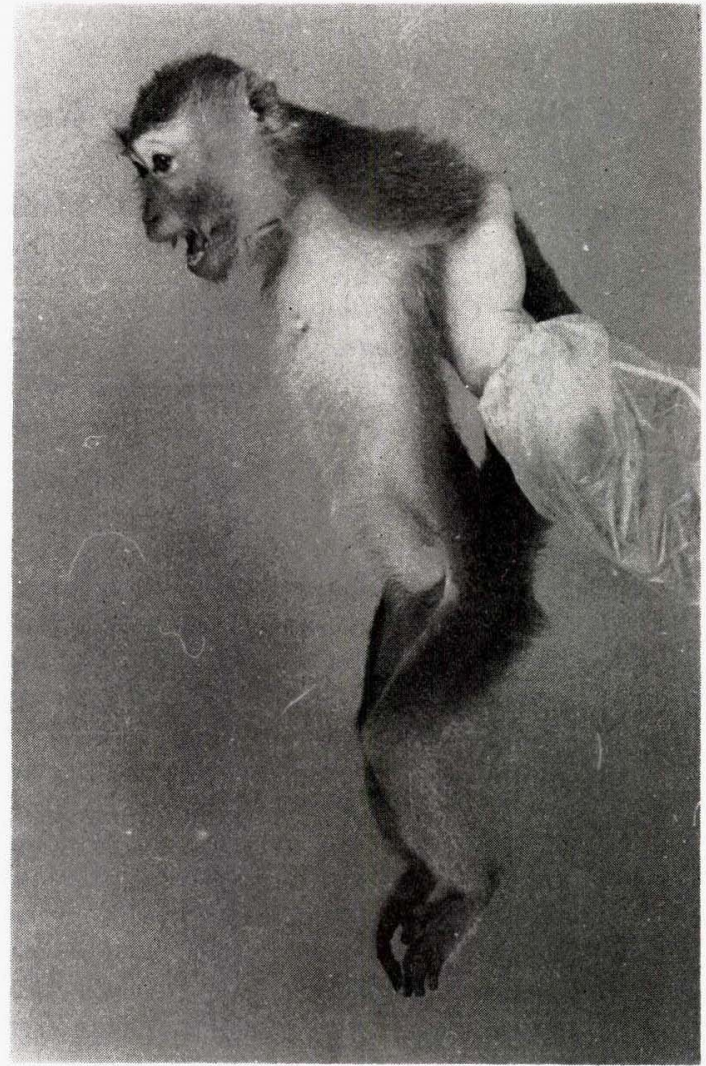

Fig. 3 The 1st step of procedures for putting the loop on : A monkey is caught at arms reaching back by an animal technician.

ルが口を開けたところで素早く $20 \mathrm{~cm}$ チューブを開口部 にかけここで $20 \mathrm{~cm}$ チューブが両側口角を圧定するよ らに紐を後方へ引く（Fig. 5)。次いで $5 \mathrm{~cm}$ チューブを サルの後頭部まで移動させることにより紐のずれ動きを 防ぐようにする(Fig. 6)。最後に紐をサルの両腕を把握 している手の第 2 指と第 3 指に巻きつける (Fig. 7,8)。 離脱方法 : まず第 2 指と第 3 指に巻きついている紐を はずし， $5 \mathrm{~cm}$ チューブをサルの後頭部より離す。次に 紐と $5 \mathrm{~cm}$ チュブを持ち，20cmチューブがサルのロの 前に出るように操作する。

Table 1 に本具の着脱時間を検討した成績を示した。 術者は A, B , C , Dの 4 人であって, いずれも約 1 年 の経験を有する飼育技術員である。用いた動物は体重 4 $\mathrm{kg}$ 以下の野生由来カニクイザル10頭である。装着時間に ついてみると飼育技術員 $\mathrm{A}$ は平均 5.5 秒, Bは4.7秒, C は4.2秒，Dは 5.4 秒であり， 4 名の平均装着時間は 4.9 
Table 1 Time spent for putting the loop on and off

\begin{tabular}{c|c|c}
\hline \multirow{2}{*}{$\begin{array}{c}\text { Animal } \\
\text { technician }\end{array}$} & \multicolumn{2}{|c}{ Time for putting } \\
\cline { 2 - 3 } & on & off \\
\hline A & $5.5 \pm 0.6$ & $3.5 \pm 1.3$ \\
B & $4.7 \pm 0.9$ & $2.4 \pm 0.7$ \\
C & $4.2 \pm 1.1$ & $2.2 \pm 0.9$ \\
D & $5.4 \pm 1.9$ & $2.4 \pm 0.6$ \\
\hline Average & $4.9 \pm 1.3$ & $2.6 \pm 1.0$ \\
\hline
\end{tabular}

*Av. \pm S. D. (Seconds) was calculated on the basis of data obtained by using 10 cynomogus monkeys weighing $3-4 \mathrm{~kg}$ for each technician.

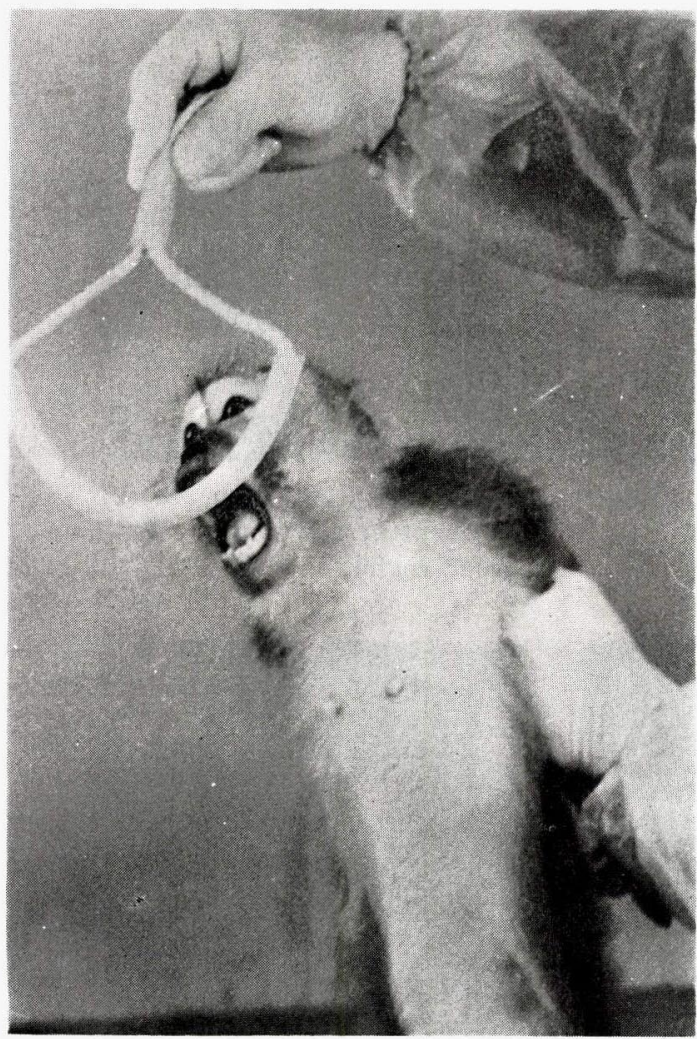

Fig. 4 The 2nd step of procedures for putting the loop on: The $20 \mathrm{~cm}$ teflon tube is brought close to the mouth of the monkey.

秒であった。離脱時間についてみると飼育技術員 Aは平 均3.5秒，Bは2.4秒， Cは2.2秒，Dは2.4秒であり 4 名 の平均離脱時間は 2.6 秒であった。以上のごとく本具の

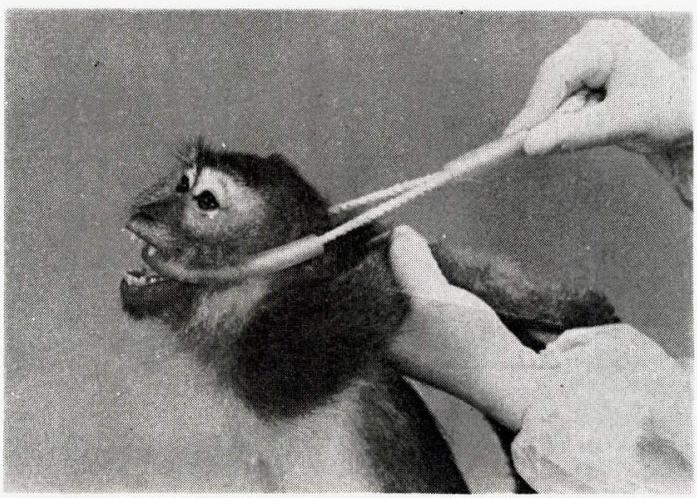

Fig. 5 The $3 \mathrm{rd}$ step of procedures for putting the loop on: The loop is pulled back, gently pressing the mouth corners.

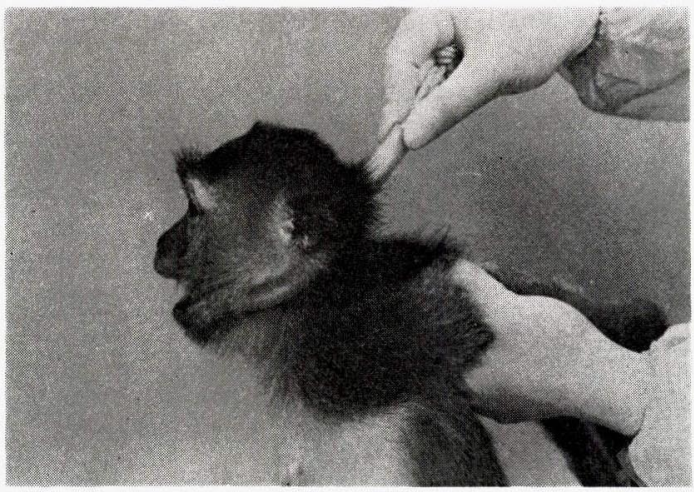

Fig. 6 The 4th step of procedures for putting the loop on: The $5 \mathrm{~cm}$ teflon tube is fixed at the back of the monkey's head, so that the loop does not slip out of the mouth corners.

着脱は極めて容易である。

\section{使 用 例}

本具の使用例を $2 \cdot 3$ 紹介する。

Fig. 9 は大腿静脈よりの採血作業である。この際サ ルの頭部を保定する手は本具未使用時に比べてずっと軽 く添える程度でよい。術者および保定者はサルの口に気 を配らなくてすみ，採血作業に集中することができる。

Fig. 10 は頸部付近の治療作業である。このように本 具着用によりサルの口の周辺部位についても安心して治 療作業を行らことができる。

Fig. 11 は背部の治療作業である。この場合, 保定者 は片手でサルの片腕を持ち他方の手でサルの頭部を抑兄 る。 


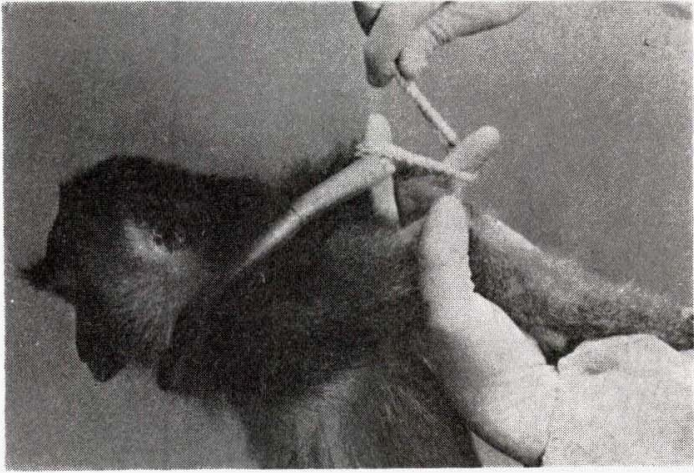

Fig. 7 The 5 th step of procedures for putting the loop on: The end of the loop is wound round the tops of both the 2nd and 3rd fingers of the animal technician holding arms of the monkey.

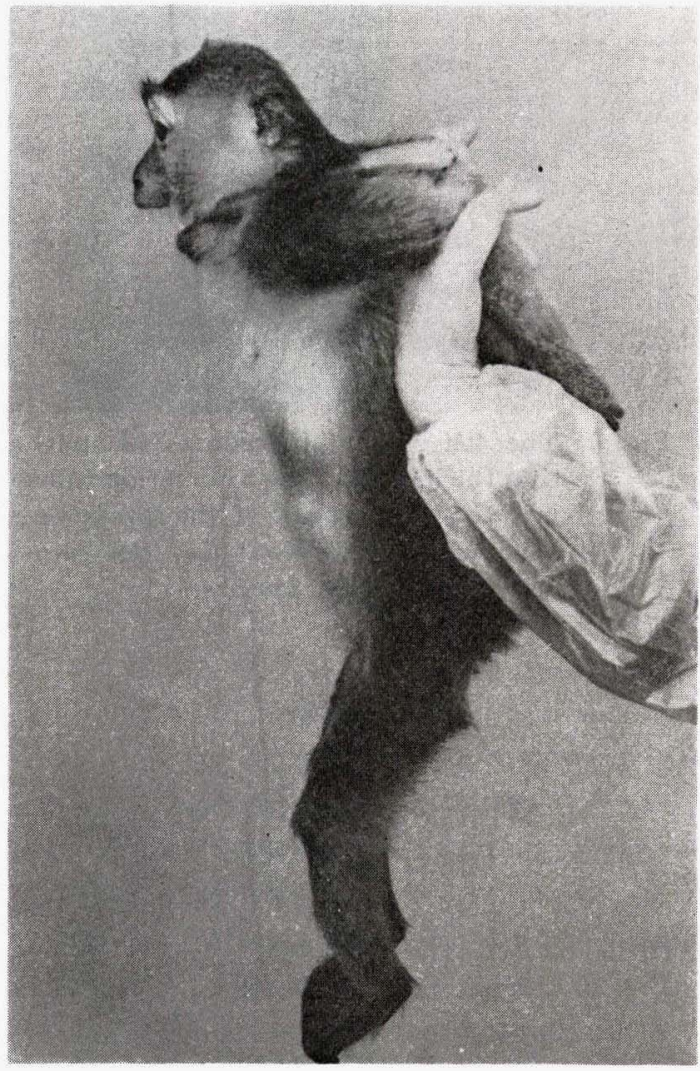

Fig. 8 Completion of putting the loop on.

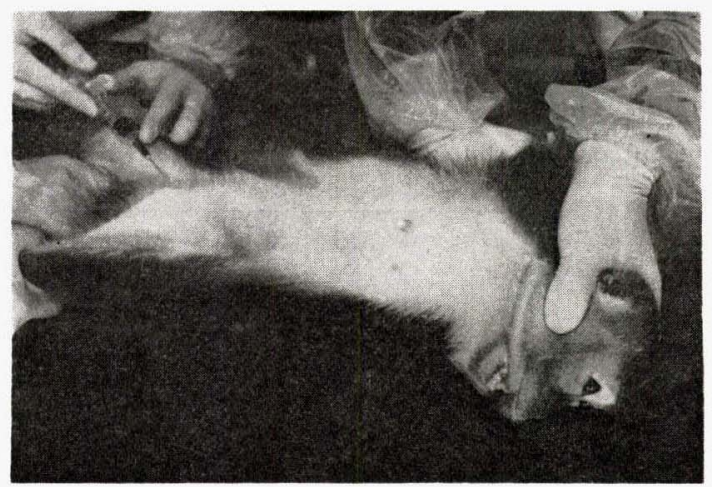

Fig. 9 An example of the loop use (1).

Blood taking from the femoral vein.

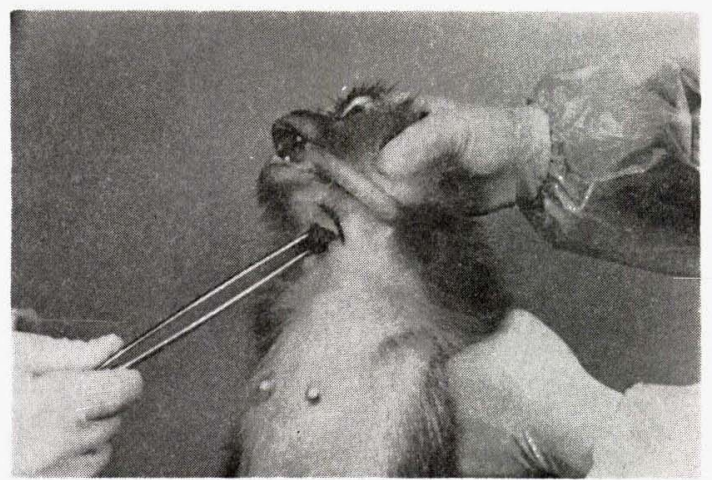

Fig. 10 An example of the loop use (2). Treatment of a wound at the mandibular region.

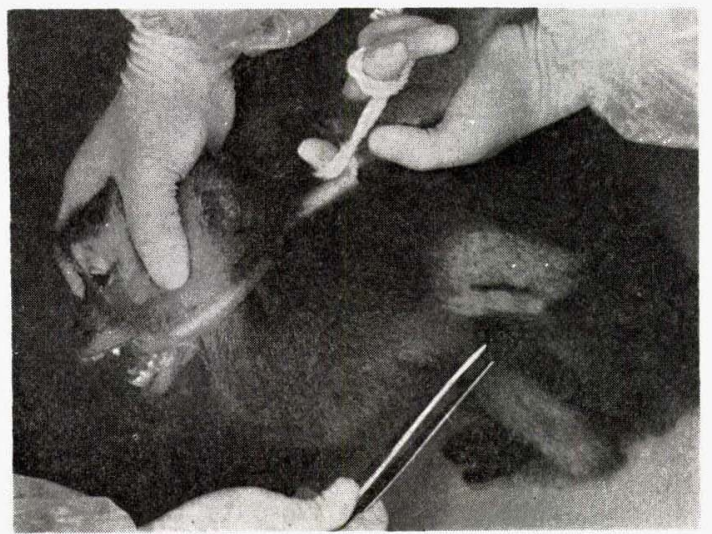

Fig. 11 An example of the loop use (3). Treatment of a wound at the flank or near there. 
なお，これらの使用から，本具はかなり耐久性があり， 約 100 回もの使用によってテフロンチューブがようやく 切れはじめること，カニクイザルの個体によっては口角 部にごく軽い傷ができることもあることを経験した。

\section{むすひ}

以上のごとく極めて簡単なカニクイザル 用保定補助 具を考案し, 体重 $4 \mathrm{~kg}$ 以下のカニクイザル（Macaca fascicularis）を用いてその実用性を検討した結果，充 分に有用であることが示された。

\section{要 約}

カニクイザル（マカカ属）を, 無麻酔下で腕部把持法 を用いて作業する際, 安全に取扱いのできる極めて簡単 な補助具を考案した。それは Fig. 2 に示したものであ り，使用方法は Fig. 3〜8 亿示した。これを実際に頻 回使用した結果, 以下のことが明らかとなった。(1)本具 の着脱は極めて容易である。(2)本具によりサルは歯を咬 み合せることができなくなるので，保定者および術者は サルの口の位置に関係なく安心して, 治療・投与・材料 採取・触診等の諸作業を行らことができる。(3)洗湺・消
毒・滅菌を容易に行らことができる。また保管場所が狭 くてすむ。(4)作製が極めて簡単かつ安価である。(5)かな り耐久性がある。すなわち約 100 回もの使用によってテ フロンチューブがようやく切れはじめた。(6)個体によっ ては口角部にごく軽い傷ができることもあった。

本稿の概要は1979年 8 月の第 14 回日本実験動学会にて報告し た。

\section{文献}

[1] Bennett J. Cohen and Max M. Bree (1978). J. med. Primatol, 7, 193-201.

[2] Frank G. Fielder and Charles J. Casmer(1966). Lab. Ani. Care, 16, 395-402.

[3] Ackerley. E. T and P. B. Stones (1969). In Hazards of Handling Simians, Laboratory Animal Handbooks 4. 207-211, F. T. Perkins and P. N. O'Donoghue (edit), Laboratory animals, London.

[4] George C. Engstrom (1970). Lab. Anim. Care, 20, 112-113.

５］本庄重男・長文昭（1977）。 マカカ属サル，実験動物学技術 編, 312-346. 田鸠嘉雄編, 朝倉書店, 東京. 